\title{
Analisis Risiko Paparan Debu Kapas Terhadap Kejadian Bisinosis di Industri Tekstil PT. Grandtex Bandung
}

\author{
Risk Assessment Of Cotton Dust Exposure to The Incidence of Byssinosis In PT. Grandtex \\ Textil Industry Bandung
}

\author{
Sri Slamet Mulyati, Onny Setiani, Mursid Raharjo
}

\begin{abstract}
Background: Byssinosis is still health problems associated with exposure to cotton dust. High risk of health problems in Environmental Health Risk Assessment is expressed as a Risk Quotenit (RQ). Work activities, the use of personal protective equipment, and psychological disorder may also affect the incidence of byssinosis.

Methods: This was an observational research with cross sectional design. The population in this research are all employees of PT.Grandtex.Eighty workers from morning shifts only were randomly selected. Each worker was examined of the FEVI and FVC. Questionnaires structured was another tools for collecting data.Total dust measured in the working environments and ambient air.

Results: The results by Chi-Square test showed significant relation between the Risk Quotenit (RQ) with byssinosis (p-value 0.043; PR 1,8 (95\%CI : 0.95-3.52), have a significant relationship between work activities with byssinosis ( $p$-value 0.035; PR 2.2 (95\%CI : 0.86-5.85)have a significant relationship between the use of personal protective equipment with byssinosis (p-value 0.001; PR 2.9 (95\%CI : 1.21-6.81) and have a significant relationship between psychological disorders with byssinosis (p-value 0.023; PR 1,7 (95\%CI : 1.28-2.14)

Conclusion: The number of worker with positive Byssinosis symptoms and abnormal lung function 15 people(18.75\%), positive Byssinosis symptoms and normal lung function 35people(43.75\%)
\end{abstract}

Keywords : Byssinosis, cotton dust, risk assessment

\section{PENDAHULUAN}

Keberadaan debu kapas dianggap menjadi penyebab penyakit paru-paru yang disebut bisinosis. Secara umum bisinosis ini cenderung merupakan sebuah symptom atau gambaran klinis yang cukup baik untuk diagnosa awal. ${ }^{1,2}$ Indonesia telah memiliki sistem pelaporan Penyakit Akibat Kerja, tetapi dataPenyakit Akibat Kerja yang terdapat di Kementerian Tenaga Kerja danTransmigrasi RI tidak dapat menjelaskan keadaan Penyakit Akibat Kerja yangsebenarnya terjadi di Indonesia. ${ }^{3}$

Sebuah penelitian di Irak menunjukkan prevalensi bisinosis terbesar terjadi pada kelompok umur 51-65 tahun yaitu 49,3\% dan pada kelompok dengan durasi kerja $>30$ tahun yaitu 49,2\%. ${ }^{4}$. Jumlah karyawan PT.Grandtex tahun 2014 ini mencapai 1653 orang. Secara keseluruhan ada 15 departemen dengan 9 bagian produksi yang terkait langsung dengan pajanan debu dalam beraktifitasnya. Bagian-bagian tersebut diantaranya adalah Blowing Spinning 3, Open End Spinning 4, Carding Spinning 1, Ring Spinning 1, Persiapan Ball Warpher, Persiapan Re Beamer,R.Boiler $\mathrm{mg} / \mathrm{m}^{3}$ ).Sementara kadar debu total ambien di area pabrik berkisar antara 0,10$0,18 \mathrm{mg} / \mathrm{m}^{3} .^{5}$ Dalam kurun waktu 3 tahun, ada 4 departemen produksi yang karyawannya banyak berkunjung ke Batubara, Weaving Sulzer II, dan Weaving Sulzer I.

Berdasarkan laporan hasil pengujian oleh balai Hyperkes Provinsi Jawa Barat tanggal 10 Maret 2014, didapat kadar debu total tertinggi di lingkungan kerja sebesar 2,74 mg/m $\mathrm{m}^{3} \mathrm{di}$ lokasi Blowing Spining 3 . Urutan terbesar selanjutnya adalah di bagian weaving sulzer II $\left(2,28 \mathrm{mg} / \mathrm{m}^{3}\right)$, dan bagian persiapan ball warpher $\left(1,46 \mathrm{mg} / \mathrm{m}^{3}\right)$.Sementara kadar debu total ambien di area pabrik berkisar antara 0,10$0,18 \mathrm{mg} / \mathrm{m}^{3,5}$ Dalam kurun waktu 3 tahun, ada 4 departemen produksi yang karyawannya banyak berkunjung ke poliklinik karena keluhan ISPA dibandingkan dengan departemen lainnya. Keempat departemen tersebut yaitu spinning ring, spinning open end, persiapan, dan weaving. ${ }^{6}$

\section{MATERI DAN METODE}

Penelitian ini dilakukan di PT.Grandtex Bandng. Jenis rancangan penelitian yang digunakan adalah observasional analitik dengan pendekatan cross sectional. Besar sampel pada penelitian ini adalah 80 responden. Parameter lingkungan yang diukur adalah kandungan debu total (TSP) di dalam ruangan 
(indoor) bagian produksi dan udara ambien untuk non produksi.Variabel yang diteliti adalah nilai Risk Quotient (RQ), aktifitas pekerjaan, penggunaan Alat Pelindung Diri, dan gangguan psikologis Pengumpulan data dilakukan dengan menggunakan kuesioner, disamping itu juga dilakukan perhitungan risiko secara kuantitiatif dengan metode Analisis Risiko Kesehatan Lingkungan (ARKL) untuk mengestimasi besar risiko individu atau populasi terhadap debu total. Observasi terhadap subjek penelitian secara langsung adalah melakukan penimbangan berat dan tinggi badan dan uji fungsi paru. Analisis data yang digunakan adalah uji chisquare

\section{HASIL DAN PEMBAHASAN}

Pengukuran debu total dilakukan di dalam lingkungan kerja (indoor) dan udara ambien (outdoor). Lokasi pengukuran dipusatkan di bagian produksi yaitu unit spinning ring, spinning open end, weaving sulzer, dan weaving picanol. Sementara satu titik sebagai pembanding dilakukan di udara ambien area pabrik. Pengukuran dilakukan oleh instruktur Laboratorium Kesling Poltekkes Bandung.Total jumlah karyawan PT.Grandtex adalah 1653 orang. Ada 899 orang $(54,39 \%)$ karyawan yang bekerja di unit produksi spinning dan weaving masing-masing 567 orang dan 332 orang, 209 orang (12,64\%) karyawan bekerja di unit non produksi (administrasi), dan selebihnya 545 orang $(32,97 \%)$ karyawan di unit lainnya.Jumlah karyawan yang berpartisipasi dalam penelitian ini sebanyak 80 orang. Subjek penelitian dari unit spinning berjumlah 40 orang karyawan, unit weaving 25 orang karyawan, dan unit administrasi 15 orang karyawan

Tabel 1 berikut adalah hasil pengukuran debu total di lingkungan kerja dan udara ambien.

Tabel 1. Hasil Pengukuran Debu Total di Lingkungan Kerja dan Ambien Tahun 2015

\begin{tabular}{llcccc}
\hline No. & Lokasi & $\begin{array}{c}\text { Hasil Pengukuran } \\
\left(\mathrm{mg} / \mathrm{m}^{3}\right)\end{array}$ & $\begin{array}{c}\text { Suhu }\left({ }^{\circ} \mathrm{C}\right) \\
\text { Kelembaban } \\
(\%)\end{array}$ & $\begin{array}{c}\text { Baku Mutu } \\
\left(\mathrm{mg} / \mathrm{m}^{3}\right)\end{array}$ \\
\hline 1 & Spinning & 0,325 & 23 & 51 & 0,15 \\
2 & Weaving & 1,070 & 23 & 52 & 0,15 \\
3 & Area Pabrik & 0,005 & 24 & 51 & 0,15 \\
\hline
\end{tabular}

Karakteristik subjek penelitian untuk data numerik seperti berat badan (BB), tinggi badan (TB) dan Indeks Massa Tubuh (IMT) disajikan dalam tabel
2 beserta parameter lain yang diperlukan untuk melakukan estimasi risiko.

Tabel 2.Karakteristik Subjek Penelitian dan Variabel Input Untuk Estimasi Risiko Paparan Debu Kapas

\begin{tabular}{|c|c|c|c|c|}
\hline \multirow{3}{*}{ Variabel } & \multicolumn{3}{|c|}{ Unit produksi } & \multirow{3}{*}{$\mathrm{P}$ value* } \\
\hline & Spinning & Weaving & Administrasi & \\
\hline & mean & mean & Mean & \\
\hline Umur (tahun) & 45,55 & 45,64 & 37,20 & 0,000 \\
\hline Berat badan $(\mathrm{Kg})$ & 58,45 & 60,40 & 62,60 & 0,203 \\
\hline Tinggi badan $(\mathrm{cm})$ & 158,92 & 160,96 & 165,53 & 0,007 \\
\hline Indeks Massa Tubuh $\left(\mathrm{Kg} / \mathrm{m}^{2}\right)$ & 23,18 & 23,38 & 23,20 & 0.958 \\
\hline Konsentrasi $\left(\mathrm{mg} / \mathrm{m}^{3}\right)$ & 0,325 & 1,070 & 0,005 & 0,000 \\
\hline Laju inhalasi (m³/jam) & 0,664 & 0,662 & 0,665 & 0,643 \\
\hline Waktu pajanan/hari (jam/hari) & & & & Homogen \\
\hline $\begin{array}{l}\text { Frekuensi pajanan tahunan } \\
\text { (hari/tahun) }\end{array}$ & & & & Homogen \\
\hline Durasi pajanan (tahun) & 25,39 & 25,04 & 12,73 & 0,000 \\
\hline Periode waktu rata-rata (hari/tahun) & & & & Homogen \\
\hline
\end{tabular}

*Uji T Independen dan Mann Whitney unit produksi vs non produksi

Nilai rerata umur terendah ( mean $=37,20)$ terdapat pada kelompok karyawan dari unit administrasi.Karakteristik umur menunjukkan adanya perbedaan yang bermakna ( $\mathrm{p}$ value $=0,000$ ) antara kelompok unit produksi dan non produksi.Nilai rerata tinggi badan terendah ( mean $=158,92$ ) terdapat pada kelompok karyawan dari unit spinning. Karakteristik tinggi badan menunjukkan adanya perbedaan yang bermakna ( $\mathrm{p}$ value $=0,007$ ) antara kelompok unit produksi dan non produksi.Nilai rerata konsentrasi 
debu total tertinggi ( mean=1,070) terdapat pada unit weaving. Karakteristik konsentrasi debu total menunjukkan adanya perbedaan yang bermakna ( $\mathrm{p}$ value $=0,000$ ) antara unit produksi dan non produksi.Nilai rerata durasi pajanan terendah $($ mean $=12,73)$ terdapat pada kelompok karyawan dari unit administrasi. Karakteristik durasi pajanan menunjukkan adanya perbedaan yang bermakna ( $\mathrm{p}$ value $=0,000)$ antara kelompok unit produksi dan non produksi.Adapun tabel analisis deskriptif karakteristik subjek penelitian untuk data katagorik terlihat pada tabel 3 .

Tabel 3. Karakteristik Subjek Penelitian

\begin{tabular}{|c|c|c|c|c|}
\hline \multirow{4}{*}{ Variabel } & \multicolumn{4}{|l|}{ Unit } \\
\hline & \multicolumn{2}{|l|}{ Produksi } & \multirow{2}{*}{ Administrasi } & \multirow{2}{*}{$\mathrm{P}$ value* } \\
\hline & Spinning & Weaving & & \\
\hline & $\mathrm{n}(\%)$ & $\mathrm{n}(\%)$ & $\mathrm{n}(\%)$ & \\
\hline Jenis kelamin & & & & 0,881 \\
\hline Laki-laki & $24(46,15)$ & $18(34,62)$ & $10(19,23)$ & \\
\hline Perempuan & $16(57,14)$ & $7(25,00)$ & $5(17,86)$ & \\
\hline Tingkat Pendidikan & & & & 0,030 \\
\hline SLTP & $18(64,29)$ & $8(28,57)$ & $2(7,14)$ & \\
\hline SLTA & $22(47,83)$ & $15(32,61)$ & $9(19,56)$ & \\
\hline Akademi/Perguruan tinggi & $0(0,00)$ & $2(33,33)$ & $4(66,67)$ & \\
\hline Aktifitas olahraga & & & & 0,341 \\
\hline Rutin & $2(33,33)$ & $2(33,33)$ & $2(33,33)$ & \\
\hline Tidak rutin & $38(51,35)$ & $23(31,08)$ & $13(17,57)$ & \\
\hline Penggunaan APD & & & & 0,152 \\
\hline Menggunakan APD & $9(56,25)$ & $6(37,50)$ & $1(6,25)$ & \\
\hline Tidak menggunakan APD & $31(48,44)$ & $19(29,69)$ & $14(21,87)$ & \\
\hline Aktifitas pekerjaan & & & & 0,000 \\
\hline Beban kerja normal & $2(20,00)$ & $2(20,00)$ & $6(60,00)$ & \\
\hline Beban kerja berlebih & $38(54,28)$ & $23(32,86)$ & $9(12,86)$ & \\
\hline Kebiasaan Merokok & & & & 0,737 \\
\hline Merokok & $11(37,93)$ & $12(41,38)$ & $6(20,69)$ & \\
\hline Tidak merokok & $29(56,90)$ & $13(25,50)$ & $9(17,60)$ & \\
\hline Gangguan psikologis & & & & 0,638 \\
\hline Terganggu & $6(42,86)$ & $6(42,86)$ & $2(14,28)$ & \\
\hline Tidak terganggu & $34(51,51)$ & $19(28,79)$ & $13(19,70)$ & \\
\hline Riwayat pekerjaan & & & & 0,491 \\
\hline Berisiko & $1(50,00)$ & $1(50,00)$ & $0(0,00)$ & \\
\hline Tidak & $39(50,00)$ & $24(30,80)$ & $15(19,20)$ & \\
\hline
\end{tabular}

* Uji chi-square unit produksi vs non produksi

Tingkat pendidikan karyawan unit produksi adalah 26 orang $(92,9 \%)$ tamat SLTP, 37 orang $(80,4 \%)$ tamat SLTA, dan 2 orang $(33,3 \%)$ tamat akademi/perguruan tinggi. Sedangkan tingkat pendidikan karyawan unit non produksi adalah 2 orang $(7,1 \%)$ tamat SLTP, 9 orang $(19,6 \%)$ tamat SLTA, dan 4 orang $(66,7 \%)$ tamat akademi/perguruan tinggi. Beban kerja berlebih dirasakan oleh 61 orang $(87,2 \%)$ karyawan unit produksi sedangkan unit non produksi dirasakan oleh 9 orang $(12,9 \%)$. Selain tingkat pendidikan dan aktifitas pekerjaan $(\mathrm{p} \leq 0,05)$, hasil uji statistik menunjukkan tidak adanya perbedaan yang bermakna antara karakteristik subjek penelitian pada kelompok unit produksi dan non produksi.
Seluruh karyawan yang terpilih sebagai sampel melakukan uji fungsi paru. Pengukuran fungsi paru dilakukan oleh 2 orang tenaga medis, yaitu dokter dan perawat dari instansi BKOM (Balai Kesehatan Olahraga Masyarakat) Bandung. Penetapan kriteria gangguan fungsi paru adalah berdasarkan American Thoraxic Society (ATS). Berikut adalah hasil pengukuran fungsi paru karyawan dari unit produksi (spinning dan weaving), dan unit non produksi (administrasi) : 
Tabel 4. Hasil Pemeriksaan Spirometri Karyawan PT. Grandtex Tahun 2015

\begin{tabular}{llllllll}
\hline \multicolumn{7}{c}{ Hasil Pengukuran } & \multicolumn{2}{l}{$\begin{array}{l}\text { Fungsi Paru } \\
\text { n }(\%)\end{array}$} \\
\cline { 3 - 7 } No. & Unit & FVC & FEV & Normal & Kelainan & Kelainan & Kelainan \\
& & mean & mean & & Restriktif & Obstruktif & Kombinasi \\
\hline 1 & Spinning & 92,42 & 80,20 & $22(55,00)$ & $6(15,00)$ & $9(22,50)$ & $3(7,50)$ \\
2 & Weaving & 97,04 & 81,52 & $18(72,00)$ & $0(0,00)$ & $5(20,00)$ & $2(8,00)$ \\
3 & Adm & 97,60 & 84,13 & $11(73,33)$ & $0(0,00)$ & $4(26,67)$ & $0(0,00)$ \\
& Jumlah & & & $51(63,75)$ & $6(7,50)$ & $18(22,5)$ & $5(6,25)$ \\
\hline
\end{tabular}

Kelainan restriktif hanya terjadi pada unit spinning $(15 \%)$ dari 40 orang karyawan yang diperiksa fungsi parunya. Kelainan obstruktif terjadi pada semua unit baik produksi maupun non produksi dengan persentase terbesar pada unit administrasi $(26,67 \%)$ dari 18 karyawan yang dinyatakan kelainan obstruktif. Sedangkan kelainan kombinasi hanya terjadi pada unit spinning 3 orang $(7,50 \%)$ dan weaving 2 orang $(8,00 \%)$. Total Jumlah karyawan yang mengalami gangguan fungsi paru adalah 29 orang (36,25\%), dengan persentase terbesar adalah karyawan yang mengalami gangguan fungsi paru katagori obstruktif 18 orang (22,5\%).Proses estimasi besar risiko gangguan kesehatan akibat debu total meliputi tahapan-tahapan seperti identifikasi bahaya, analisis dosis respon, analisis pajanan, dan karakterisasi risiko. ${ }^{12}$ Karakterisasi risiko merupakan tahap akhir dalam analisis risiko, di sini dilakukan penentuan karakter atau sifat risiko dari agen risiko.Risiko bahaya akibat pajanan kronis dinyatakan sebagai Risk Quotient $(R Q)$, dihitung dengan cara membagi asupan (I)dengan dosis referensi ( $R f D$ atau $R f C$ ). Di bawah ini adalah tabel distribusi nilai Risk Quotient karyawan bagian produksi dan non produksi.

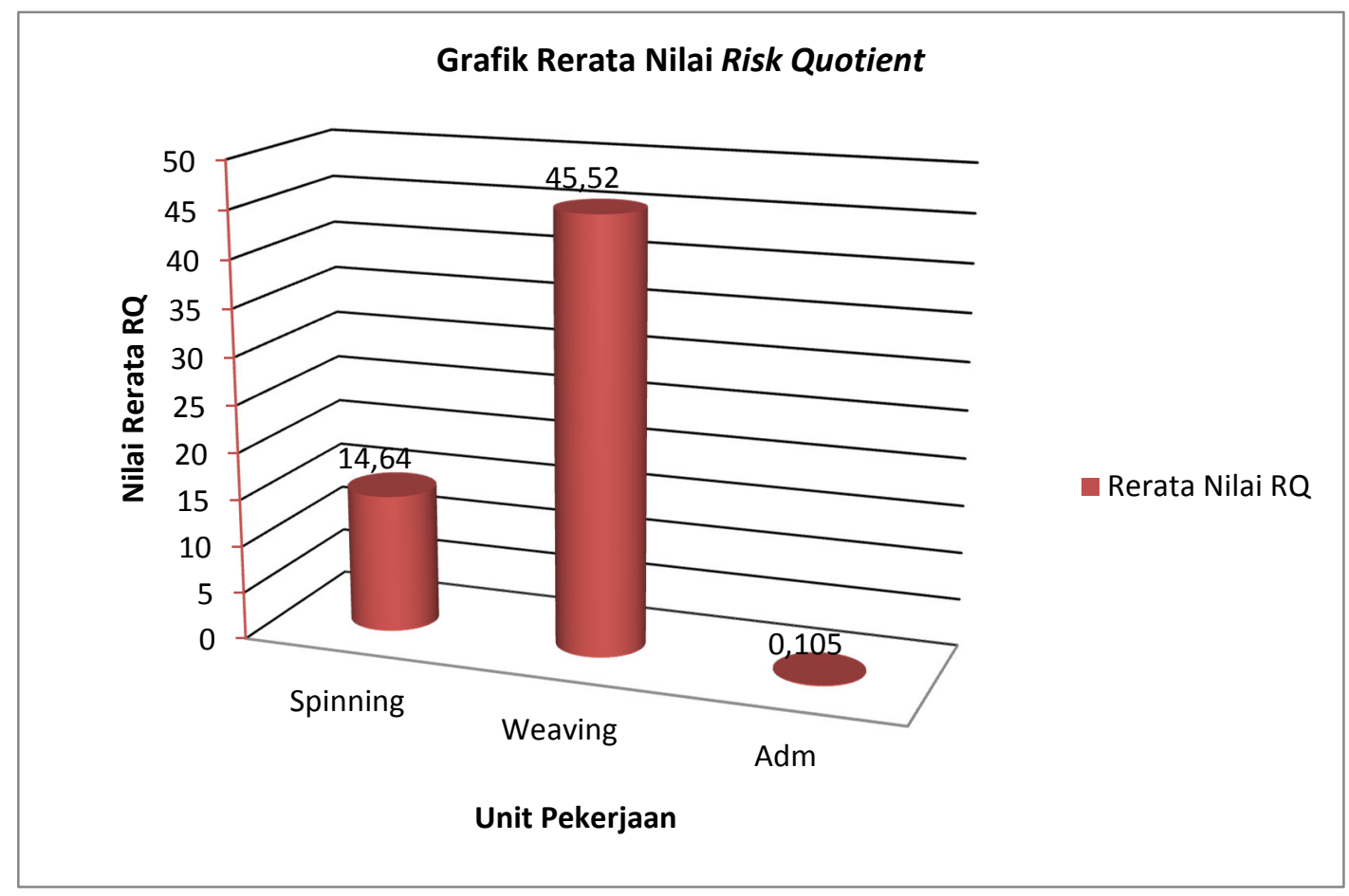

Gambar 1. Distribusi Nilai Risk Quotient Karyawan Menurut Unit Pekerjaan di PT. Grandtex Tahun 2015 
Nilai Risk Quotient (RQ) > 1 artinya suatu individu atau populasi berisiko mengalami gangguan kesehatan. Semakin besar nilai Risk Quotient (RQ) semakin besar pula peluang untuk mengalami gangguan kesehatan. Unit weaving lebih besar peluangnya untuk mengalami gangguan kesehatan dibandingkan dengan unit spinning. Sementara prevalensi gejala bisinosis pada setiap unit pekerjaan digambarkan dalam grafik berikut ini :

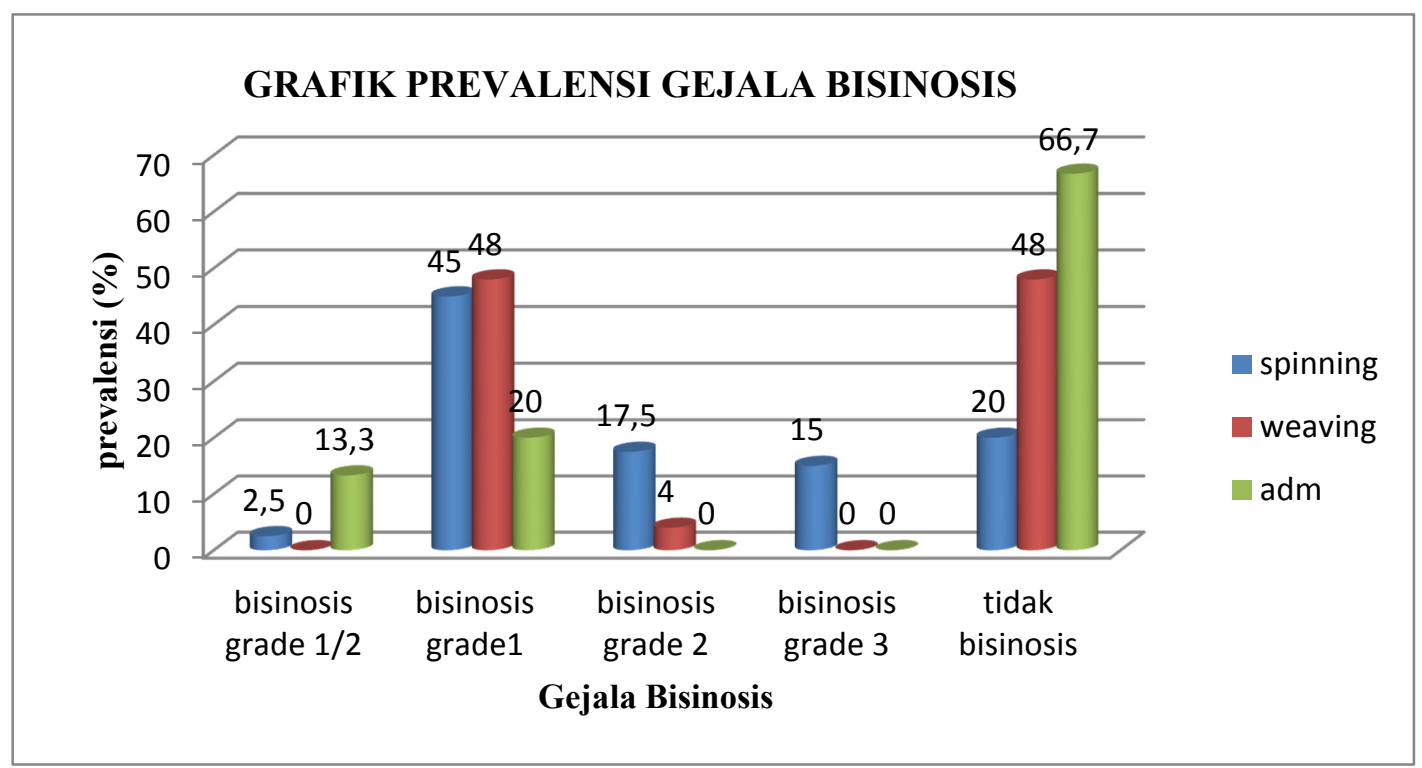

Gambar 2. Point Prevalensi Gejala Bisinosis Karyawan Menurut Unit Pekerjaan di PT. Grandtex Tahun 2015

Prevalensi gejala bisinosis grade $1 / 2$ tertinggi terjadi pada unit administrasi, grade 1 tertinggi pada unit weaving, sementara grade 2 dan 3 tertinggi pada unit spinning.Kejadian bisinosis didefinisikan sebagai semua tingkatan (all grade) gejala bisinosis dari $1 / 2$ sampai dengan 3 dengan atau tanpa gangguan fungsi paru digambarkan dalam tabel berikut :

Tabel 5. Grade Bisinosis dan Fungsi Paru Karyawan PT. Grandtex Tahun 2015

\begin{tabular}{lccccc}
\hline & \multicolumn{5}{c}{ Fungsi Paru } \\
\cline { 2 - 5 } Grade Bisinosis & $\begin{array}{c}\text { Normal } \\
\mathrm{n}(\%)\end{array}$ & $\begin{array}{c}\text { Kelainan } \\
\text { Restriktif } \\
\mathrm{n}(\%)\end{array}$ & $\begin{array}{c}\text { Kelainan } \\
\text { Obstruktif } \\
\mathrm{n}(\%)\end{array}$ & $\begin{array}{c}\text { Kelainan } \\
\text { Kombinasi } \\
\mathrm{n}(\%)\end{array}$ & $\begin{array}{c}\text { Total } \\
\mathrm{n}(\%)\end{array}$ \\
\hline Grade 0 & $16(53,33)$ & $0(0,00)$ & $12(40,00)$ & $2(6,67)$ & $30(37,5)$ \\
Grade 1/2 & $2(66,67)$ & $0(0,00)$ & $1(33,33)$ & $0(0,00)$ & $3(3,75)$ \\
Grade 1 & $31(93,94)$ & $0(0,00)$ & $2(6,06)$ & $0(0,00)$ & $33(41,25)$ \\
Grade 2 & $2(25,00)$ & $0(0,00)$ & $3(37,50)$ & $3(37,5)$ & $8(10)$ \\
Grade 3 & $0(0,00)$ & $6(100)$ & $0(0,00)$ & $0(0,00)$ & $6(7,5)$ \\
jumlah & $51(63,75)$ & $6(7,50)$ & $18(22,50)$ & $5(6,25)$ & $80(100)$ \\
\hline
\end{tabular}

Tabel 5 menunjukkan bahwa karyawan yang positif mempunyai gejala bisinosis berdasarkan hasil anamneses dengan kuesioner standard (grade 1/2-3) diikuti dengan variasi kapasitas fungsi paru. Katagori fungsi paru dari mereka ada yang tergolong normal, mengalami kelainan restriktif, obstruktif, dan kombinasi. Berikut di bawah ini adalah grafik kejadian bisinosis (all grade) dengan atau tanpa gangguan fungsi paru dihubungkan dengan nilai Risk Quotient(RQ) : 


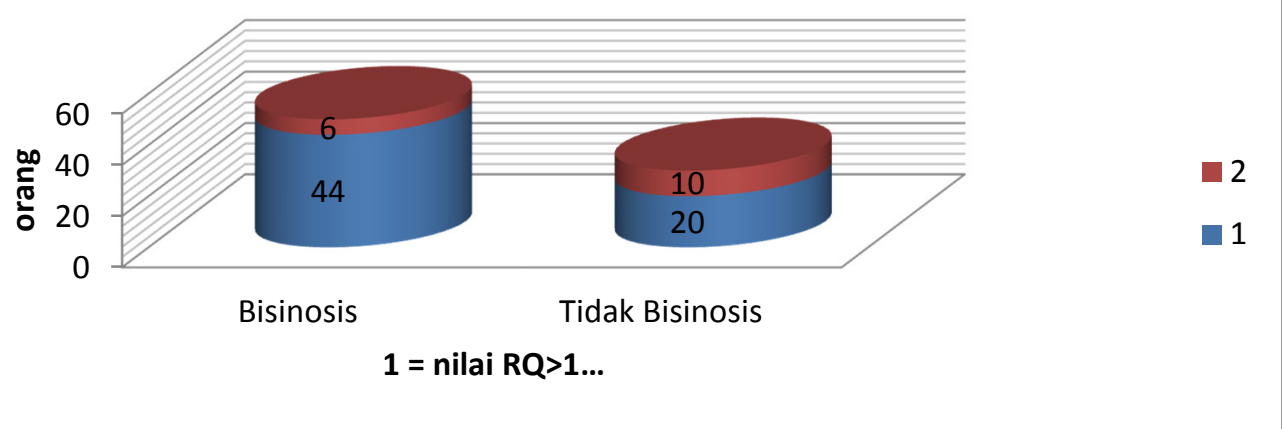

Gambar 3. Distribusi Kejadian Bisinosis Karyawan PT. Grandtex Tahun 2015

Hasil uji statistik menunjukkan nilai p value $<0,05$, artinya ada hubungan yang bermakna antara besar nilai Risk Quotient(RQ) dengan kejadian
bisinosis.Berikut ini adalah hasil rangkuman analisis bivariat antara variabel bebas dan pengganggu dengan kejadian bisinosis di PT.Grandtex Bandung :

Tabel 6. Rangkuman Hasil Analisis Chi-squareantara Variabel Bebas dan Pengganggu dengan Kejadian Bisinosis di PT.Grandtex Tahun 2015

\begin{tabular}{rlcccl}
\hline No. & Variabel & Nilai p & RP & $95 \%$ CI & Keterangan \\
\hline 1. & Nilai Risk Quotient (RQ) & 0,043 & 1,833 & $0,953-3,525$ & Signifikan \\
2. & Aktifitas Pekerjaan & 0,035 & 2,238 & $0,856-5,850$ & Signifikan \\
3. & Penggunaan Alat Pelindung & 0,001 & 2,875 & $1,214-6,811$ & Signifikan \\
& Diri (APD) & & & & \\
4. & Gangguan Psikologis & 0,023 & 1,656 & $1,279-2,145$ & Signifikan \\
5. & Kebiasaan Merokok & 0,615 & 0,828 & $0,565-1,212$ & Tidak signifikan \\
6. & Riwayat Pekerjaan & 0,525 & 1,625 & $1,364-1,937$ & Tidak signifikan \\
7. & Status Gizi & 0,816 & 0,928 & $0,658-1,309$ & Tidak signifikan \\
8. & Olahraga & 0,190 & 1,946 & $0,620-6,109$ & Tidak signifikan \\
\hline
\end{tabular}

Tabel 6 menunjukkan bahwa semua variabel bebas yang diteliti seperti nilai Risk Quotient (RQ), aktifitas pekerjaan, penggunaan Alat Pelindung Diri (APD), dan gangguan psikologis berhubungan dengan kejadian bisinosis.

\section{PEMBAHSAN}

Rata-rata berat badan karyawan unit spinning $58,45 \mathrm{Kg}$, unit weaving $60,40 \mathrm{Kg}$, dan unit administrasi $62,60 \mathrm{Kg}$.Rata-rata lama kerja atau durasi pajanan karyawan unit spinning 25,4 tahun, unit weaving 25,04 tahun, dan unit administrasi 12,7 tahun. Hasil uji statistik menunjukkan bahwa ada perbedaan yang bermakna rata-rata lama kerja karyawan bagian produksi (unit spinning dan weaving) dengan bagian non produksi (administrasi), $\mathrm{p}$ value0,000.Semakin lama pajanan debu total terhadap karyawan semakin besar pula intake debu total yang diterima karyawan tersebut. Hal ini terjadi karena konsentrasi pajanan polutan dalam perhitungan intake berbanding lurus dengan durasi pajanan. ${ }^{8}$ Ratarata nilai Risk Quotient (RQ) unit spinning 14,64, unit weaving 45,52, dan unit administrasi 0,105. Semakin besar nilai RQ semakin besar pula peluang untuk terjadinya gangguan kesehatan akibat pajanan debu total di industri tekstil.Unit weaving memiliki nilai
RQ tertinggi dibandingkan dengan unit lainnya, hal ini disebabkan unit tersebut berada di lokasi yang berkadar debu total tertinggi pula yakni 1,070 $\mathrm{mg} / \mathrm{m}^{3}$.Sebuah penelitian tentang analisis risiko polutan udara (TSP) di 9 kota besar di Indonesia terhadap gangguan kesehatan menunjukkan bahwa besar nilai Risk Quotient dipengaruhi oleh keberadaan tempat atau area. Tempat yang banyak atau dekat dengan sumber polutan mempunyai frekuensi kejadian tingkat bahaya yang berisiko kesehatan (Risk Quotient $>1) .{ }^{9}$ Pengukuran kadar debu merupakan bagian dari analisis pajanan dalam Analisis Risiko Kesehatan Lingkungan (ARKL).Karyawan yang bekerja di bagian produksi khususnya pemintalan dan tenun terpapar secara langsung oleh debu tersebut saat proses produksi berlangsung. Atas dasar tersebut maka pengukuran pajanan dilakukan secara langsung di area lingkungan kerja tersebut. Dalam direct exposure ini, karyawan secara rutin datang dan berinteraksi dengan risk agent atau agen risiko yang dilepaskan ke dalam lingkungan kerja.?

Kejadian bisinosis di PT.Grandtex ditetapkan berdasarkan kriteria BMRC karena pengukuran sampai grade 3 . Karyawan yang mempunyai gejala positif baik grade 1/2, 1, 2 maupun 3 dinyatakan sebagai bisinosis. Selanjutnya karyawan yang 
dinyatakan bisinosis maupun tidak bisinosis berdasarkan gejala yang muncul, diperiksa fungsi parunya dan dilakukan analisis deskriptif. Prevalensi gejala bisinosis untuk semua grade (1/2-3) adalah 62,5 $\%$. Jumlah karyawan dengan gejala bisinosis $(+)$ dan fungsi paru tidak normal 15 orang $(18,75 \%)$, gejala bisinosis $(+)$ dan fungsi paru normal 35 orang $(43,75 \%)$. Sementara karyawan dengan gejala bisinosis (-) dan fungsi paru tidak normal 14 orang $(17,5 \%)$, gejala bisinosisi (-) dan fungsi paru normal 16 orang $(20 \%)$.

Hasil uji statistik antara nilai Risk Quotient dengan kejadian bisinosis menunjukkan hubungan yang bermakna ( $\mathrm{p}$ value $=0,043$ ).Nilai Risk Quotient merupakan sebuah besaran nilai probabilitas di mana penggunaanya selama ini dapat memberikan informasi telah atau belum berisikonya individu atau populasi terhadap pajanan polutan tertentu. Kelengkapan data numerik untuk menghitung nilai Risk Quotient dapat mengestimasi kemungkinan terjadinya efek gangguan kesehatan terhadap polutan tertentu. Namun demikian analisis risiko kualitatif lainnya dari individu atau populasi akan lebih melengkapi dan menyempurnakan upaya-upaya penetapan karakterisasi risiko. ${ }^{10}$ Aktifitas pekerjaan dengan kejadian bisinosismenunjukkan hubungan yang bermakna dilihat dari $\mathrm{p}$ value 0,035 (95\% CI 1,128-20,156). Seperti disebutkan dalam laporan International Labour Organization (ILO) tahun 2014 bahwa risiko yang muncul di tempat kerja diantaranya adalah kondisi ergonomis yang buruk, radiasi gelombang elektromagnetik, beban mental dan psikologis yang tinggi. ${ }^{11}$ Respon psikologi yang muncul dapat berupa perasaan terbebani dengan pekerjaan, merasa dikejar waktu, tidak ada waktu untuk mengembangkan karir dan lain-lain. Karakteristik individu yang mudah stress, beban kerja ringan pun akan terasa berat apalagi yang sesungguhnya berat. Pekerjaan yang menuntut beban mental dan psikologis yang tinggi dapat memicu stress.

Hasil uji statistik menunjukkan adanya hubungan yang bermakna ( $\mathrm{p}$ value $=0,001)$. Sebanyak 21 orang $(44,7 \%)$ karyawan yang tidak menggunakan APD mengalami gangguan fungsi paru, ini bukanlah jumlah yang sedikit walaupun hasil uji statistik tidak menunjukkan adanya perbedaan yang bermakna antara karyawan yang menggunakan APD dan tidak menggunakan APD dengan gangguan fungsi paru. Karyawanyang berisiko terpapar polutan udara perlu mempertimbangkan klasifikasi kelengkapan proteksi sistem pernafasan atau Respiratory Protective Devices (RPD). Kelengkapan proteksi harus mempunyai klasifikasi yang jelas, apakah sebagai filtering devices atau sebagai breathing devices. ${ }^{12}$ Bagi karyawan yang berisiko terpapar polutan udara di tempat kerjanya maka kemampuan alat proteksi harus berfungsi melawan polutan partikel, gas, uap, atau kombinasinya.

\section{SIMPULAN}

Ketiga data pajanan tersebut (masa kerja , berat badan, dan konsentrasi debu total) menghasilkan ratarata nilai Risk Quotient (RQ) unit spinning 12,202, weaving 37,93, dan unit non produksi 0,0876 . Berdasarkan nilai Risk Qoutient tersebut, unit produksi telah berisiko mengalami gangguan kesehatan akibat pajanan debu total (nilai Risk Quotient $>1$ ), sedangkan unit non produksi belum berisiko (nilai Risk Quotient $\leq 1$. Kejadian bisinosis all grade $62,5 \%$, jumlah karyawan dengan gejala bisinosis $(+)$ dan fungsi paru tidak normal 15 orang $(18,75 \%)$, gejala bisinosis $(+)$ dan fungsi paru normal 35 orang $(43,75 \%)$.Ada hubungan yang bermakna antara nilai Risk Quotient dengan kejadian bisinosis (p value 0,043). Ada hubungan yang bermakna antara aktifitas pekerjaan dengan kejadian bisinosis ( $\mathrm{p}$ value 0,035). Ada hubungan yang bermakna antara penggunaan APD dengan kejadian bisinosis ( $\mathrm{p}$ value 0,001). Ada hubungan yang bermakna antara gangguan psikologis dengan kejadian bisinosis ( $p$ value 0,023 )

\section{SARAN}

1. Melakukan reduksi hazard kesehatan misalnya dengan menggunakan penyedot udara (exhaust fan) sehingga mengencerkan kadar debu total yang berterbangan di udara lingkungan kerja, menggunakan teknik basah (wet process) dengan melakukan penyiraman polutan

2. partikel agar tidak berterbangan dan jatuh di sepanjang jalur produksi

3. Sebaiknya ada pembatasan masa kerja di unit produksi khususnya spinning dan weaving, dan perlunya pemeriksaan kesehatan berkala untuk karyawan di unit tersebut

\section{DAFTAR PUSTAKA}

1. Niven R, Pickering CAC. Byssinosis and related diseases dalam dalam Diffuse Lung Disease Caused by Cotton Fibre Inhalation but Distinct from Byssinossis. H Kobayashi, S Kanol, K Motoyoshi and S Aida. Thorax 2004:59:10951097.

2. Merchant JA. Byssinosis. Occupational respiratory diseases dalam Diffuse Lung Disease Caused by Cotton Fibre Inhalation but Distinct from Byssinossis. H Kobayashi, S Kanol, K Motoyoshi and S Aida. Thorax 2004:59:10951097.

3. Ichsan P. Nila. Sistem Pelaporan Penyakit Akibat Kerja di Kota Administrasi Jakarta Utara.

4. Wahab Z. Faktor-faktor yang Berhubungan dengan Timbulnya Gangguan Fungsi Paru dan Kejadian Bisinosis pada Karyawan Pabrik Tekstil X di Semarang (Tesis). 2001.

5. Balai Hiperkes dan Keselamatan Kerja Bandung. Laporan Hasil Pengujian. 2014. 
6. Rekam Medis Poliklinik Perusahaan PT.Grandtex; 2012-2014.

7. Glossary of Air Pollution Terms .CARB.2000 dalam IPCS. Harmonization of Approach to the Assessment of Risk from Exposure to Chemicals.

8. Louvar FL and Louvar BD.Health \& Environmental Risk Analysis Fundamental With Application. Vol (2), New Jersey: Prentice Hall PTR.1998.

9. Numan A, Rahman A, Warouw S, Setiadi MI, dan Akib CR. Analisis dan Manajemen Risiko Kesehatan Pencemaran Udara : Studi Kasus di Sembilan Kota Besar Padat Transportasi. Jurnal Ekologi Kesehatan. Pusat Kajian Kesehatan Lingkungan dan Industri, FKM UI.2005.Vol.4 No.2.

10. Rahman A. Prinsip-prinsip Dasar, Metode, Teknik, dan Prosedur Analisis Risiko Kesehatan Lingkungan. Depok : Pusat Kajian Kesehatan Lingkungan dan Industri FKM UI ; 2005.

11. ILO. Creating Safe and Healthy Workplaces for All.2014.

12. PPE Against Hazardous Substances In Textile Industry. Gaziantep (Turkey), 4-5 march 2010. 